\title{
Use of CAMEL Model: A Study on Financial Performance of Selected Commercial Banks in Bangladesh
}

\author{
Golam Mohiuddin \\ Institute of Education, Research and Training (IERT), University of Chittagong, Chittagongg-4331, Bangladesh \\ *Corresponding Author: gmuddiniert@cu.ac.bd
}

Copyright $@ 2014$ Horizon Research Publishing All rights reserved.

\begin{abstract}
Banking sector is one of the fastest growing sectors in Bangladesh. Modern banking sector is becoming more complex than before. Evaluating Bangladeshi banking sector is challenging task. There are so many factors, which need to be taken care while differentiating good banks from bad ones. Sound financial health of a bank is the guarantee not only to its depositors but is equally significant for the shareholders, employees and whole economy of a country as well. As a result to this statement, efforts have been made from time to time, to measure the financial position of each bank and manage it efficiently and effectively. In this study, an effort has been made to evaluate the financial performance of the two major banks (one is NCB and another one is PCB) operating in Bangladesh. This evaluation has been done by using CAMEL Parameters, the latest model of financial analysis. Through this model, it is highlighted that the position of the banks under the study is sound and satisfactory so far as their capital adequacy, asset quality, management capability and liquidity is concerned.
\end{abstract}

Keywords Capital Adequacy, Asset Quality, Management Capability, Financial Performance, Commercial Banks, Earnings Analysis, Liquidity Analysis

\section{Introduction}

With the integration of Bangladeshi financial sector the concept of banks and banking has undergone a standard shift. Before financial reforms, Bangladeshi Banks were enjoying, in a protected environment with a strong cushion of the government and their banks. This had made them operationally inefficient and commercially almost spoil, as they had cumulated as much as about TK.23,000.00 crores as Non-performing advances. However, with the Bangladesh Bank taking strong measures based on the recommendations of the reform committee, the landscape of Bangladeshi banking changed altogether. All the banks were directed to follow the norms of capital adequacy, asset quality, provisioning for NPAs, prudential norms, disclosure requirements, acceleration of pace and reach of latest technology, streamlining the procedures and complying with accounting standards and making financial statements transparent. Towards this end, they re-defined their objectives, strategies, policies, processes, methods and technologies which have a direct bearing on the financial health and performance of these banks. In this way, these banks were not only required to take the above steps but always evaluate their financial position from period to period. Because of this factor, the interest of the analysts and researchers got developed to analyze, evaluate, measure and finally manage the financial performance of the Bangladeshi banks.

\section{Literature Review}

In this route, the researchers like Chidambaram and Alemelu (1994), Sarkar and Das(1997), Ajit and Bangar (1998), Bhatia and Verma (1998), Kaur and Bhatia (1998), Padmanabhan (1998), Dasgupta (2000), Desai and Farmer (2001), Edirisuriya and Fang (2001), Mittal (2001), Passah (2001), Sikander and Mukherjee (2001), Khatik (2002), Sangmi (2002), Purohit,et al (2003), Kapil and Nagar (2003), Duncan et al (2004), Reddy (2004) and Mohanty (2006) have attempted to make a contribution in the field. Among all these researchers, no one has used the latest technique of CAMEL Parameters to study the financial performance of the Indian banks. It is against this backdrop that the present study has been undertaken to fill up this gap.

\section{Objectives of the Study}

The main objectives of the study are as follows:

(i) to analyses the financial performance of the banks under study;

(ii) to undertake the factors which have led to the current financial performance; and

(iii) to suggest measures, on the basis of the study results, to improve further the financial performance of the banks under study. 


\section{Methodology of the Study}

Methodology describes the research route to be followed, the instruments to be used, universe and sample of the study for the data to be collected, the tools of analysis used and pattern of deducing conclusions. For the purpose of the study, the research instrument used is the CAMEL Model which is the recent innovation in the area of financial performance evaluation of banks. The model is explained as under:

\subsection{CAMEL Parameters}

This system was adopted in Bangladesh since 1995 at the suggestion of Bangladesh Bank (the central bank of Bangladesh). Under this system the rating of individual banks is done along five key parameters- Capital adequacy, Asset quality, Management capability, Earnings capacity, and Liquidity. Each of the five dimensions of performance is rated on a scale of 1 to 5, varying from fundamentally strong bank to fundamentally weak bank. This model has been applied in the following select banks.

\subsection{Samples of the Study}

The present study seeks to evaluate the financial performance of the two top banks of Bangladesh, representing the biggest nationalized commercial bank (i.e. Sonali Bank Limited, SBL) and the biggest private commercial bank (i.e. AB Bank Limited, ABBL). These two banks were purposely selected for the study, keeping in view their role and involvement in shaping the economic conditions of Bangladesh, specifically in terms of advances, deposits, manpower employment and branch network etc.

\subsection{Data and Tools}

The present study is mainly based on secondary data drawn from the annual reports of the respective banks. This data is related to 5 years (2009-2013). For analysis of the data, two important statistical tools viz. mean and standard deviation has been used to arrive at conclusions in a scientific way.

\section{Findings and Discussion}

The results and discussions of the study are described under the following heads:

- Capital adequacy analysis

- Asset quality analysis

- Management capability analysis

- Earnings analysis; and

- Liquidity analysis

\subsection{Capital Adequacy Analysis}

Capital adequacy is a reflection of the inner strength of a bank, which would stand it in good stead during the times of crisis. Capital adequacy may have a bearing on the overall performance of a bank, like opening of new branches, fresh lending in high risk but profitable areas, manpower recruitment and diversification of business through subsidiaries or through specially designated branches, as the Bangladesh Bank (the central bank of Bangladesh) could think these operational dimensions to the bank's capital adequacy achievement. Realizing the importance of capital adequacy, the BB issued directive whereby each banks in Bangladesh was required to meet the capital adequacy standard of $10 \%$, the norm fixed on the basis of the recommendations of Basel Committee. As a sequel to this direction almost all banks in Bangladesh try to adhere to this norm, thus compute the ratios of capital adequacy. The computation of capital adequacy ratio is done by taking ratio of equity capital and loan loss provisions minus non-performing loans to total assets. Expressed as a percentage, the ratio shows the ability of a bank to withstand losses in the value of its assets. The simultaneous monitoring of two important elements, viz. the level of NPAs and equity capital is facilitated by the use of this ratio. For computation of the capital adequacy ratio, capital is classified as Tier-1 and Tier-2 capitals. Tier-1 capital comprises the equity capital and free reserves, while Tier- 2 capital comprises subordinated debt of 5-7 year tenure. The higher the capital adequacy ratio (CAR), the stronger the bank, however, a very high CAR indicates that the bank is conservative and has not utilized the full potential of its capital. The capital adequacy ratios of the banks under study are given in tables 1 and 2 .

Table 1. Capital Adequacy Ratios of Sonali Bank Limited (SBL)

\begin{tabular}{|c|c|c|c|c|c|c|c|}
\hline $\begin{array}{c}\text { Capital Adequacy } \\
\text { Ratios }\end{array}$ & 2009 & 2010 & 2011 & 2012 & 2013 & Mean & S.D. \\
\hline $\begin{array}{c}\text { Capital Adequacy } \\
\text { Ratio }\end{array}$ & $10.040 \%$ & $10.490 \%$ & $11.780 \%$ & $12.840 \%$ & $14.490 \%$ & $11.928 \%$ & 1.806 \\
\hline $\begin{array}{c}\text { Leverage Ratio } \\
\text { Net worth } \\
\text { Protection }\end{array}$ & 1.726 & 1.648 & 1.548 & 1.838 & 1.790 & 1.711 & 0.116 \\
\hline
\end{tabular}

Source: Department of Off-site Supervision, Bangladesh Bank. Calculation: calculated by researcher himself. 
Table 2. Capital Adequacy Ratios of AB Bank Limited (ABBL)

\begin{tabular}{|c|c|c|c|c|c|c|c|}
\hline Capital Adequacy Ratios & 2009 & 2010 & 2011 & 2012 & 2013 & Mean & S.D. \\
\hline Capital Adequacy Ratio & $17.090 \%$ & $15.150 \%$ & $16.150 \%$ & $16.540 \%$ & $14.840 \%$ & $15.950 \%$ & 0.942 \\
\hline Leverage Ratio & 1.192 & 0.889 & 0.692 & 0.584 & 0.687 & 0.808 & 0.241 \\
\hline Net worth Protection & 28,210 & 38,748 & 48,108 & 54,610 & 51,485 & 44,232 & 10,748 \\
\hline
\end{tabular}

Source: Department of Off-site Supervision, Bangladesh Bank. Calculation: calculated by researcher himself.

The position of capital adequacy of the Sonali Bank Limited (SBL) has been measured with the help of Capital Adequacy Ratio (CAR), Leverage ratio and Net worth protection. An introspection of the table 1 reveals that the capital adequacy ratio of the SBL in the last five years has been well above the norm of BB i.e. $10 \%$ level. This ratio has been increasing year after year $10.04 \%$ in the year 2009 and $14.49 \%$ in the year 2013 . The average of the five years also is good $11.928 \%$ which seems quite consistent as standard deviation being only 1.806 . Similarly the leverage ratio (Total outside liability to shareholders funds also show a healthy sign; Although the ratio declined from 1.726 in 2009 to 1.648 in 2010 , but has picked up in the subsequent years. However, the mean value of the leverage ratio is 1.70 with 0.116 deviations. So far as net worth protection (Net Worth to Non-Performing assets) is concerned. The ratio has been all along rising during the period under study with 7,559.91 in 2009 to $21,376.74$ in 2013 with the mean value 11,000.50.To maintain the capital adequacy, the bank has mobilized capital from the stock market. Thus the bank has been able to maintain the confidence of investors and depositors. The position of capital adequacy of the AB Bank Limited (ABBL) has been measured with the help of Capital Adequacy Ratio (CAR), Leverage ratio and Net worth protection. An introspection of the table 2 reveals that the capital adequacy ratio of the ABBL in the last five years has been well above the norm of BB i.e. 10\% level, although decreasing year after year $17.09 \%$ in the year 2009 and $14.85 \%$ in the year 2013 . But still it is comfortably much above the minimum stipulated standard. The average of the five years also is good $15.95 \%$ which seems quite consistent as standard deviation being only 0.942 .

Similarly, the leverage ratio (Total outside liability to shareholders funds) also shows a bit weak sign as the ratio declined from 1.192 in 2009 to 0.889 in 2010 and has gone down in the subsequent years. The mean value of the leverage ratio is 0.808 and standard deviation is 0.241 . The bank needs to be careful here about the declining trend of leverage ratio. So far as Net worth protection (Net worth to Non-performing assets) is concerned, the ratio has been all along rising during the period under study with 28,210 in 2009 to 51,485 in 2013 with the mean value 44,232 . To maintain the capital adequacy, the bank has mobilized capital from the stock market. Thus the bank has been able to maintain the confidence of investors and depositors. Also the bank continued its efforts to reduce its non-performing assets.
With the strenuous efforts and enhanced recovery drive coupled with stress on sound asset quality and prevention of fresh slippages, the bank has been able to further reduce its NPA level. Which has strengthened its capital base as otherwise too many loss making efforts would have eroded the capital position of the bank.

\subsection{Assets Quality Analysis}

Asset quality is another important aspect of the evaluation of a bank's performance under the Reserve Bank of India guidelines, the advances of a bank are to be disclosed in a classified manner as:

- Standard;

- Sub-Standard; and

- Doubtful and loss asset.

\subsubsection{Standard Asset/Advance}

Standard assets are those assets that are performing and loan holder is paying interest and installment at due date, further they do not carry more than normal risk. Formerly, no provisions were required. However, banks will now have to make a general provision of 0.25 percent on standard assets as well.

\subsubsection{Sub-standard Asset/Advance}

Sub-standard assets are those assets that have been classified as non-performing for a period less than or equal to three quarters. In such cases, the current net worth of the borrower/guarantor or the current market value of the security charged is not enough to ensure recovery fully. It has fully developed weaknesses that jeopardize the liquidation of a debt.

\subsubsection{Doubtful Asset/Advance}

Doubtful assets are those assets that have remained substandard for 18 months. The provisions of $100 \%$ of the provisions are to be made by the realizable value of the security to which a bank has recourse. The provisions for this are to be done as:

first year of doubtful status $\quad$-Deficit $+20 \%$ of security; second year of doubtful status -Deficit $+30 \%$ of security; third year of doubtful status -Deficit $+50 \%$ of security.

\subsubsection{Loss Asset/Advance}

Loss assets are the ones where loss has been identified but 
the amount has not been written off wholly or partly. Such an asset is uncollectible or unrecoverable and of such little value that its continuance as a bankable asset is not warranted although there may be some salvages value. Since the loss assets are to be written off, $100 \%$ provision needs to be made for loss assets. Under the above classification, the advance/asset which ceases to earn income/interest is termed as non-performing asset and a bank has to keep a provision for its probable loss. More NPAs mean more sub-standard, doubtful and loss assets which is total for the future financial performance of a bank. Therefore, keeping the NPAs minimum should be the attempt of every conscious bank. The main ratios of asset quality of the banks under study are given in tables 3 and 4 .

The analysis in table 3 reveals that the SBL has been successful to manage its NPAs. The Net NPAs which were $6.60 \%$ of total Net advances of the bank in 2009 have come down to $0.19 \%$ in 2013 . This has been possible by using various strategies by the bank. The bank through a well-defined Recovery Management Policy, was able to effect reduction of TK. 1614 crore in NPAs during the year as against TK 1326 crore last year. NPAs with outstanding of TK. 1 crore and above continued to be monitored at corporate level. The bank also made effective use of the recommendations of banks reform committee.

Moreover, under the scheme of one time settlement of the cases for small and marginal farmers, NPAs to the tune of TK. 502 lakhs were cleared during the period 2012-2013. Thus the bank has been able to manage the Net NPA to Net Advances at an average of $3.351 \%$. To be secure and safe the bank has been maintaining the provisions for NPAs as per norms fixed by BB. It has been in a position to consistently maintain such provision with $9.226 \%$ of Gross NPAs in 2009 with an average of $8.114 \%$ having standard deviation of 2.156. In this way the asset quality position of the bank seems good as the loan loss cover for NPAs has been provided prudently. Under BB's non-discretionary and non-discriminatory guidelines for compromise settlements, there was an encouraging response from the borrowers. During April-October, 2012, settlements were approved in 2218 cases for TK. 43.57 crores. Recovery of NPAs received focused attention. Apart from other recovery efforts, the bank also organized 17561 Recovery Camps during the year 2012-2013 compared to 14556 camps organized in the previous year. In most of such camps locally elected representatives also participated. Awareness campaigns for recovery were also launched in different Zones. Besides these, services of Debt Recovery Tribunals were also utilized for supplementing the recovery efforts. The bank also initiated the process of engaging Recovery Agencies for effecting recovery in NPAs. A special drive was launched in the bank towards execution of decrees allowed by the courts. In deserving cases, restructuring of debts under CDR mechanism was pursued with encouraging results.

The analysis in table 4 reveals that the ABBL has been successful to manage its NPAs. The Net NPAs which were $2.40 \%$ of total Net advances of the bank in 2009 have come down to $1.38 \%$ in 2013 . This has been possible by using various strategies by the bank. The bank continued its efforts to reduce its non-performing assets. With the strenuous efforts and enhanced recovery drive, the bank has been able to further reduce its NPA level. Thus the bank has been successful to manage the Net NPA to Net Advances at an average of $1.72 \%$. To be secure and safe, the bank has been maintaining the provisions for NPAs as per norms fixed by BB. It has been in a position to consistently maintain such provision with $8.517 \%$ of Gross NPAs in 2009 with an average of $9.334 \%$ having standard deviation of 2.71 . In this way, the asset quality position of the bank seems quite good as the loan loss cover for NPAs has been provided prudently.

Table 3. Asset Quality Ratios of Sonali Bank Limited (SBL)

\begin{tabular}{|c|c|c|c|c|c|c|c|}
\hline Asset Quality Ratios & 2009 & 2010 & 2011 & 2012 & 2013 & Mean & S.D. \\
\hline Net NPA to Net Advances & $6.600 \%$ & $5.210 \%$ & $3.780 \%$ & $0.960 \%$ & $0.190 \%$ & $3.340 \%$ & 2.730 \\
\hline Loan Loss Cover & $9.226 \%$ & $9.078 \%$ & $9.307 \%$ & $8.415 \%$ & $4.402 \%$ & $8.085 \%$ & 2.112 \\
\hline
\end{tabular}

Source: Department of Off-site Supervision, Bangladesh Bank. Calculation: calculated by researcher himself.

Table 4. Asset Quality Ratios of AB Bank Limited (ABBL)

\begin{tabular}{|c|c|c|c|c|c|c|c|}
\hline Asset Quality Ratios & 2009 & 2010 & 2011 & 2012 & 2013 & Mean & S.D. \\
\hline Net NPA to Net Advances & $2.400 \%$ & $1.840 \%$ & $1.540 \%$ & $1.450 \%$ & $1.380 \%$ & $1.720 \%$ & 0.416 \\
\hline Loan Loss Cover & $8.517 \%$ & $11.320 \%$ & $5.007 \%$ & $10.166 \%$ & $11.663 \%$ & $9.334 \%$ & 2.71 \\
\hline
\end{tabular}

Source: Department of Off-site Supervision, Bangladesh Bank. Calculation: calculated by researcher himself. 
Table 5. Management Capability Ratios of Sonali Bank Limited (Growth in Various Parameters)(SBL)

\begin{tabular}{|c|c|c|c|c|c|c|c|}
\hline Various Parameters & 2009 & 2010 & 2011 & 2012 & 2013 & Mean & $\begin{array}{c}\text { Compound } \\
\text { growth rate }\end{array}$ \\
\hline Advances & $27,468.46$ & $33,682.02$ & $39,423.55$ & $46,280.22$ & $59,204.49$ & $41,211.74$ & $15.68 \%$ \\
\hline Deposits & $55,008.50$ & $62,841.01$ & $74,297.22$ & $86,158.06$ & $101,103.54$ & $75,881.66$ & $12.74 \%$ \\
\hline Business & $82,476.97$ & $96,523.03$ & $113,720.77$ & $132,438.28$ & $160,308.03$ & $1,17,093.41$ & $13.72 \%$ \\
\hline Total Expenses & $5,582.75$ & $6,028.75$ & $6,289.66$ & $6,395.20$ & $7,279.75$ & $6,315.22$ & $4.90 \%$ \\
\hline Operating Profit & 926.30 & $1,444.32$ & $2,270.94$ & $3,058.44$ & $2,653.06$ & $2,070.61$ & $23.52 \%$ \\
\hline Net Profit & 454.37 & 551.14 & 825.35 & $1,086.51$ & $1,381.91$ & 859.85 & $23.53 \%$ \\
\hline Earnings Per Share & 21.41 & 25.96 & 31.74 & 40.95 & 43.82 & 32.77 & $14.70 \%$ \\
\hline
\end{tabular}

Source: Department of Off-site Supervision, Bangladesh Bank. Calculation: calculated by researcher himself

Table 6. Management Capability Ratios of Sonali Bank Limited(SBL)

\begin{tabular}{|c|c|c|c|c|c|c|c|}
\hline Management Capability Ratios & 2009 & 2010 & 2011 & 2012 & 2013 & Mean & S.D. \\
\hline Expenditure to Income Ratio & 0.839 & 0.789 & 0.719 & 0.662 & 0.717 & 0.745 & 0.069 \\
\hline Credit-Deposit Ratio & 0.489 & 0.524 & 0.519 & 0.526 & 0.573 & 0.526 & 0.031 \\
\hline Asset Utilization Ratio & 0.101 & 0.101 & 0.098 & 0.092 & 0.078 & 0.094 & 0.007 \\
\hline Diversification Ratio & $11.484 \%$ & $12.564 \%$ & $14.026 \%$ & $18.972 \%$ & $16.201 \%$ & $14.649 \%$ & 2.989 \\
\hline Earnings per Employee & 77.723 & 95.255 & 139.935 & 184.658 & 236.916 & 146.897 & 65.170 \\
\hline Expenditure per Employee & 957.443 & 1041.964 & 1066.387 & 1086.89 & 1248.04 & 1080.144 & 106.030 \\
\hline
\end{tabular}

Source: Department of Off-site Supervision, Bangladesh Bank. Calculation: calculated by researcher himself..

\subsection{Management Capability Ratios}

The performance of Management capacity is usually qualitative and can be understood through the subjective evaluation of Management systems, organization culture and control mechanisms and so on. However, the capacity of the management of a bank can also be gauged with the help of certain ratios of off-site evaluation of a bank. The capability of the management to deploy its resources, aggressively to maximize the income, utilize the facilities in the bank productively and reduce costs etc. This can be evaluated with reference to the following ratios given in tables 5, 6, 7 and 8 .

In the table 5 , it is exhibited that the SBL has been a quite successful bank so far as its business is concerned. During the period under reference the bank has been able to mark a rising trend in its advances and deposits with TK. 27,468.46 crores, and 55,008.50 crores respectively in the year 2009 to TK. 59,204.49 crores and 1,01,103.54 crores in 2013. Thus advances and deposits have registered a compound growth rate of $15.68 \%$ and $12.74 \%$ respectively, with the total fund based business (advances + deposits) marking a growth of $13.72 \%$ P.a. The management has been successful to manage a compound growth rate of $23.52 \%$ in its operating and net profits but keeping the total expenses under control, as they grew only at a growth rate of $4.90 \%$ p.a. In the similar way, the efficiency of the management is explained by the growth of earning per share it grew at about $14.70 \%$ of compound growth rate. The management capacity has also been explained in the table 6 with the help of various productivity rates, like expenditure to Income ratio, credit deposit ratio, asset utilization ratio, diversification ratio, earnings per employee and expenditure per employee. The ratio of expenditure visa viz. to Income which was 0.839 in 2009 has gone down to 0.717 , in 2013 explaining thereby that for every rupee generated as income only 0.83 paisa were incurred as cost in 2009 and so on. The mean value of this ratio is 0.74 with minor standard deviation of 0.069 is an encouraging fact. The credit deposit ratio which was 0.489 in 2009 has slightly improved to 0.573 in 2013 with the mean value 0.529 shows its consistency during the period under study. However, the asset utilization ratio which was 0.101 in 2009 has shown a declining trend as it has come down to 0.078 in 2009 , but the mean value of the ratio remains by and large consistent at 0.08 level. Since modern days, the opportunities of sustaining on spread are squeezing day in and day out, the success of any bank lies in diversifying its business from fund based business to the fee based business. In this direction, the bank under study has also achieved good results as the ratio of non-interest income to total income has increased from $11.47 \%$ in 2009 to $16.19 \%$ in 2013. This ratio has shown consistency with the average of $14.65 \%$ having a standard deviation of 2.98 . The trend in the productivity of employees so far as earnings are concerned is significantly improved. The earnings per employee were 77.91 in 2009 which has gone up to 236.91 in the year 2013, with the mean value 146.90. However, the expenditure per employee has gone up from 957.44 in 2009 to $1,248.04$ in 2013 which needs to be taken care of.

In the table 7, it is exhibited that the ABBL has been a quite successful bank so far as its fund based business is concerned. During the period under the study, the bank's business has shown a rising trend in its advances and 
deposits with TK. 4,667.63 crores, and 10,944.71 crores respectively in the year 2009 to TK. $11,286.79$ crores and $21,212.07$ crores in 2013. The advances have registered a compound growth rate of $23.52 \%$ and a growth rate of $13.72 \%$ is observed in case of deposits, with the total business marking a growth of $15.68 \%$ p.a. A further analysis of the table reveals that management has been successful to manage a compound growth rate of $4.90 \%$ and $0.98 \%$ in its operating profits and Net Profits and keeping the total expenses under control, as the expenditure only grew at a growth rate of $6.86 \%$ p.a. In the similar way, the efficiency of the management is explained by the growth of earning per share which grew at about $0.98 \%$ of compound growth rate. The Management capacity has also been explained in the table 8 with the help of various productivity ratios, like expenditure to Income ratio, credit deposit ratio, asset utilization ratio, diversification ratio, earnings per employee and expenditure per employee. The ratio of expenditure visa viz. to Income which was 0.748 in 2009 has gone slightly up to 0.766 in 2013 , explaining thereby that for every taka generated as income only 0.744 paisa were incurred as cost in 2009 and so on. The mean value of this ratio is 0.69 with minor standard deviation of 0.049 is an encouraging fact. The credit deposit ratio which was 0.417 in 2009 has slightly improved to 0.521 in 2013 with the mean value 0.47 shows its consistency during the period under study. However, the asset utilization ratio which was 0.088 in 2009 has shown a declining trend as it has come down to 0.064 in 2013, but the mean value of the ratio remains by and large consistent. So far as diversifying the business from fund based to fee based, the ABBL has not achieved good performance in the last two years as the ratio of non-interest income to total income has decreased from $6.83 \%$ in 2009 to $4.91 \%$ in 2013 . This ratio is highly skewed, with the average of $12.00 \%$ having a standard deviation of 5.63 .

The trend in the productivity of employees so far as Earnings are concerned has gone done. The earnings per employee were 253.80 in 2009 which has gone up to TK. 562.03 in 2012, however, declined to TK. $164 . .07$ in the year 2013 , with the mean value 367.50 . Similarly, the expenditure per employee has gone up from 1339.70 in 2009 to 1819.19 in 2013 which needs to be taken care of, if the banks wants to be successful in the long run.

Table 7. Management Capability Ratios of AB Bank Limited (Growth in Various Parameters)(ABBL)

\begin{tabular}{|c|c|c|c|c|c|c|c|}
\hline Various Parameters & 2009 & 2010 & 2011 & 2012 & 2013 & Mean & $\begin{array}{c}\text { Compound } \\
\text { growth rate }\end{array}$ \\
\hline Advances & $4,667.63$ & $6,295.00$ & $7,850.72$ & $9,099.23$ & $11,286.79$ & $7,839.954$ & $23.52 \%$ \\
\hline Deposits & $10,944.71$ & $12,652.88$ & $13,381.39$ & $18,288.15$ & $21,212.07$ & $15,295.890$ & $13.72 \%$ \\
\hline Business & $15,612.35$ & $18,948.29$ & $22,232.12$ & $27,387.39$ & $32,498.86$ & $23,335.800$ & $15.68 \%$ \\
\hline Total Expenses & 866.79 & $1,126.62$ & $1,137.61$ & $1,170.62$ & $1,250.27$ & $1,110.380$ & $6.86 \%$ \\
\hline Operating Profit & 267.33 & 452.01 & 542.64 & 615.85 & 348.35 & 445.230 & $4.90 \%$ \\
\hline Net Profit & 164.20 & 254.60 & 330.99 & 398.20 & 112.75 & 252.140 & $0.98 \%$ \\
\hline Earnings Per Share & 34.13 & 52.86 & 68.66 & 82.53 & 23.24 & 52.280 & $0.98 \%$ \\
\hline
\end{tabular}

Source: Department of Off-site Supervision, Bangladesh Bank. Calculation: calculated by researcher himself.

Table 8. Management Capability Ratios of AB Bank Limited(ABBL)

\begin{tabular}{|c|c|c|c|c|c|c|c|}
\hline Management Capability Ratios & 2009 & 2010 & 2011 & 2012 & 2013 & Mean & S.D. \\
\hline Expenditure to Income Ratio & 0.748 & 0.698 & 0.663 & 0.641 & 0.766 & 0.703 & 0.049 \\
\hline Credit-Deposit Ratio & 0.417 & 0.487 & 0.534 & 0.487 & 0.521 & 0.489 & 0.044 \\
\hline Asset Utilization Ratio & 0.088 & 0.106 & 0.099 & 0.083 & 0.064 & 0.088 & 0.013 \\
\hline Diversification Ratio & $6.839 \%$ & $15.641 \%$ & $16.415 \%$ & $16.219 \%$ & $4.927 \%$ & $12.008 \%$ & 5.630 \\
\hline Earnings per Employee & 253.800 & 392.000 & 465.403 & 562.036 & 164.072 & 367.462 & 159.930 \\
\hline Expenditure per Employee & $1,339.710$ & $1,734.600$ & $1,599.574$ & $1,652.272$ & $1,819.112$ & $1,629.053$ & 181.888 \\
\hline
\end{tabular}

Source: Department of Off-site Supervision, Bangladesh Bank. Calculation: calculated by researcher himself. 
Table 9. Earnings (Profitability) Ratios of Sonali Bank Limited(SBL)

\begin{tabular}{|l|l|l|l|l|l|l|l|}
\hline Earnings Ratios & 2009 & 2010 & 2011 & 2012 & 2013 & Mean & S.D. \\
\hline Return on assets & $0.714 \%$ & $0.755 \%$ & $0.956 \%$ & $1.061 \%$ & $1.094 \%$ & $0.916 \%$ & 0.173 \\
\hline Return on equity & $12.766 \%$ & $12.537 \%$ & $14.670 \%$ & $14.742 \%$ & $13.155 \%$ & $13.574 \%$ & 0.042 \\
\hline Spread ratio & 0.299 & 0.294 & 0.349 & 0.367 & 0.387 & 0.339 & 0.042 \\
\hline Net interest margin & 0.031 & 0.030 & 0.035 & 0.034 & 0.030 & 0.032 & 0.004 \\
\hline
\end{tabular}

Source: Department of Off-site Supervision, Bangladesh Bank. Calculation: calculated by researcher himself.

Table 10. Earnings (Profitability) Ratios of AB Bank limited(ABBL)

\begin{tabular}{|c|c|c|c|c|c|c|c|}
\hline Earnings Ratios & 2009 & 2010 & 2011 & 2012 & 2013 & Mean & S.D. \\
\hline Return on assets & $1.290 \%$ & $1.731 \%$ & $2.068 \%$ & $1.877 \%$ & $0.460 \%$ & $1.485 \%$ & 0.620 \\
\hline Return on equity & $20.877 \%$ & $24.861 \%$ & $24.904 \%$ & $23.691 \%$ & $6.434 \%$ & $20.153 \%$ & 7.890 \\
\hline Spread ratio & 0.301 & 0.266 & 0.300 & 0.333 & 0.357 & 0.311 & 0.036 \\
\hline Net interest margin & 0.027 & 0.028 & 0.030 & 0.028 & 0.023 & 0.027 & 0.003 \\
\hline
\end{tabular}

Source: Department of Off-site Supervision, Bangladesh Bank. Calculation: calculated by researcher himself.

\subsection{Earnings Ratios}

The 'Earnings is a Conventional Parameter of measuring financial performance. In the pre-liberalization phase (before 1991), interest income used to be reckoned on accrual basis with little variation therein. In the absence of any uniform norm on provisioning against bad debts and depreciation in investment, the variation in accounting profit was mainly due to provisions and contingencies. Some semblance of uniformity was first introduced in 1992-93 with the phased implementation of prudential accounting standards which however brought about a wide variation in the current period income, as interest income was henceforth required to be reckoned on a realization basis. However, for the present study the accounting ratios calculated for the purpose of earnings analysis are depicted in tables. 9 and 10 .

It is exhibited in the table 9 that the return on assets which is equal to Net profit to working funds has significantly gone up from $0.714 \%$ to $1.094 \%$ in the year 2009 to 2013 , with the mean value of $0.91 \%$ having consistency, as the standard deviation is 0.173 . However, the return on shareholders' funds (R.O.E) has by and large remained constant with the mean value of $13.57 \%$. In this way it seems the profitability of the bank is quite satisfactory. A further analysis of the table 9 reveals that the spread i.e. Interest earned on loans minus interest paid on deposits has been constantly rising from 0.299 in 2009 to 0.387 in 2013, with the mean value of 0.343 having a standard deviation of .042 . Similarly, the contribution of the spread visa viz to total earning asset has slightly shown a down trend from 0.031 in 2009 to 0.030 in the year 2013, with the mean value of 0.029 .

It is exhibited in the table 10 that the return on assets which is equal to Net Profit to working funds has gone down from $1.290 \%$ to $0.460 \%$ in the year 2009 to 2013 , with the mean value of $1.460 \%$ having consistency, as the standard deviation is 0.620 . However, the return on shareholders' funds (R.O.E) has by and large remained constant with the mean value of $20.15 \%$. In this way, it seems the profitability of the bank is quite satisfactory. A further analysis of the table 4.99 reveals that the spread i.e. Interest earned on loans minus interest paid on deposits has been constantly rising from 0.301 in 2009 to 0.357 in the year 2013, with the mean value of 0.31 having a standard deviation of 0.036 . Similarly, the contribution of the spread visa viz to total earning asset has slightly shown a down trend from 0.027 in 2009 to 0.023 in the year 2013, with the mean value of 0.019 .

\subsection{Liquidity Ratios}

The ability of a bank to provide liquidity requires the existence of a highly liquid and readily transferable stock of financial assets. Liquidity and transferability are the key ingredients for such transactions. The liquidity requirement means that financial assets must be available to owners on short notice (a day or less) at par. The transferability requirement means that ownership rights in financial assets must be portable, at par, to other economic agents, and in a form acceptable to the other party (Sinkey, Joseph F, JR. 1998). Liquid assets such as investment securities, enable a bank to respond quickly to unexpected demands for cash and typically reflect relatively conservative financial strategies, whereas volatile liabilities, such as large certificates of deposits, often reflect relatively aggressive financial strategies impose high interest expenses, and are subject to 
quick withdrawal. As a result, we expect higher values of investment securities to reduce the chance of failure, whereas higher values of large certificates of deposit should increase the probability of failure (Cole and Gunther, 1996). Thus liquidity management is one of the most important functions of a bank. If funds tapped are not properly utilized, the institution should suffer loss. Idle cash balance in hand has no yield. On the other hand if the bank does not keep balanced liquid cash in hand, it cannot be able to pay the demand withdrawal of depositors, as well as, installment of creditors and ultimately payment for other contingent liabilities. These will lead overtrading position to the institution and create problems to borrow funds at high rate. Proper balanced liquidity should be maintained by avoiding inadequate cash position, or excess cash position (Panigrahi, 1996). The liquidity position of the banks understudy is presented in tables 11 and 12

In the table 11, it is depicted that the liquid assets which consist of cash, balances with BB and other banks as well as money at call and short notice, formed TK. 0.093 visa viz. to taka 1 (total assets). This ratio has gone down 0.062 in 2013, but at an average it has remained consistent with average 0.078. The investment in Govt. and other securities held by the bank visa viz. to total assets are clear indicators of banks liquidity position, as this investment ratio has remained consistent around an average of 0.382 . The total liquid assets (combination of the above two ratios visa viz. to depositors has brought the fact to the forefront that the bank has the ability to meet any eventuality in case of depositors demand liquid assets, as this ratio has also remained by and large consistent at an average of 0.098 with the standard deviation of 0.011. Similarly, the investment in securities (Govt. as well others) shows a satisfactory position of the bank as the ratio of investment in securities compared to deposits also remained consistent around an average of 0.45 with 0.022 standard deviation. In the table 12, it is showed that the liquid assets which consist of cash, balances with BB and other banks as well as money at call and short notice, formed Re. 0.157 visa viz. to (total assets). This ratio has gone down 0.126 in 2013, but at an average it has remained consistent with average 0.127. The investment in Govt. and other securities held by the bank visa viz. to total assets are clear indicators of banks liquidity position, as this investment ratio has remained consistent around an average of 0.382 . The total liquid assets (combination of the above two ratios visa viz. to depositors has exposed the fact that the bank has the ability to meet any eventuality in case of depositors demand for liquid assets, as this ratio has also remained by and large consistent at an average of 0.137 with the standard deviation of 0.0284. Similarly, the investment in securities (Govt. as well others) shows a satisfactory position of the bank as the ratio of investment in securities compared to deposits also remained consistent around an average of 0.441 with 0.021 standard deviation..

Table 11. Liquidity Ratios of Sonali Bank Limited(SBL)

\begin{tabular}{|c|c|c|c|c|c|c|c|}
\hline Liquidity Ratios & 2009 & 2010 & 2011 & 2012 & 2013 & Mean & S.D. \\
\hline Liquid assets to total assets & 0.093 & 0.085 & 0.091 & 0.084 & 0.062 & 0.083 & 0.014 \\
\hline Total securities to total assets & 0.384 & 0.375 & 0.384 & 0.400 & 0.390 & 0.386 & 0.010 \\
\hline Liquid assets to deposits & 0.105 & 0.097 & 0.103 & 0.098 & 0.076 & 0.095 & 0.011 \\
\hline Investment to deposits & 0.434 & 0.427 & 0.436 & 0.466 & 0.478 & 0.448 & 0.022 \\
\hline
\end{tabular}

Source: Department of Off-site Supervision, Bangladesh Bank. Calculation: calculated by researcher himself.

Table 12. Liquidity Ratios of AB Bank Limited(ABBL)

\begin{tabular}{|c|c|c|c|c|c|c|c|}
\hline Liquidity Ratios & 2009 & 2010 & 2011 & 2012 & 2013 & Mean & S.D. \\
\hline Liquid assets to total assets & 0.157 & 0.130 & 0.088 & 0.134 & 0.126 & 0.127 & 0.024 \\
\hline Total securities to total assets & 0.412 & 0.382 & 0.392 & 0.390 & 0.362 & 0.387 & 0.017 \\
\hline Liquid assets to deposits & 0.180 & 0.148 & 0.100 & 0.152 & 0.143 & 0.144 & 0.280 \\
\hline Investment to deposits & 0.470 & 0.435 & 0.448 & 0.442 & 0.410 & 0.441 & 0.021 \\
\hline
\end{tabular}

Source: Department of Off-site Supervision, Bangladesh Bank. Calculation: calculated by researcher himself. 
Table 13. Overall Financial Performance of the Banks Under study

\begin{tabular}{|c|c|c|c|}
\hline Part & Ratios & Sonali Bank Limited (SBL) & AB Bank Limited (ABBL) \\
\hline I & Capital Adequacy & $11.928 \%$ & $15.95 \%$ \\
\hline I & Expenditure Expenses/Income & 0.745 & 0.703 \\
\hline I & Net Interest Margin & 0.032 & 0.027 \\
\hline I & Return on Assets & $0.916 \%$ & $1.468 \%$ \\
\hline I & Overall Index Rank & 1 & 2 \\
\hline II & NPA to Net Advances & $3.34 \%$ & $0.172 \%$ \\
\hline II & Index Rank & 2 & 1 \\
\hline III & Liquid assets to Total Deposits & 0.095 & 0.144 \\
\hline III & Index Rank & 2 & 1 \\
\hline
\end{tabular}

Source: Department of Off-site Supervision, Bangladesh Bank. Calculation: calculated by researcher himself.

\subsection{Overall Financial Performance of the Banks under Study}

The overall Financial Performance of the Banks as exhibited in the table 13 reveals that both the Banks have maintained their capital adequacy ratio well above the BB standard of $10 \%$. The other three ratios viz. Expenditure to Income, Net Interest Margin, and Return on Assets show a mixture of behavior, some are more in SBL and less in ABBL and vice-versa. However, the overall Index (which has been calculated by dividing the average of individual banks by the average of all items of both banks in part first of table 13) which is more in case of SBL compare to ABBL but part second and part third in the table show a reverse trend.

\section{Conclusions}

The analysis and the discussion in the proceeding pages reveal that both the banks are financially viable as both have adopted prudent policies of financial management. Both the banks have managed their capital adequacy ratio well above the minimum standard of $10 \%$ fixed by $\mathrm{BB}$. The average leverage ratio in case of SBL is more (1.711) compare to ABBL (0.808). So far as Asset quality is concerned both the banks have shown significant performance. The SBL has been able to maintain the ratio of Net NPAs to Net advances at 3.34\%. The ABBL bank has been more efficient by maintaining the average ratio of Net NPAs to Net advances at $1.720 \%$. Similarly, the average loan loss cover maintained by ABBL $(9.334 \%)$ is more than that of SBL $(8.085 \%)$. The business (Advances +Deposits) of the SBL and the ABBL have registered a compound growth rate of $28.42 \%$ \& $37.24 \%$ respectively. However, the compound growth rate of operating profit has been $23.52 \%$ in SBL and $4.90 \%$ in ABBL. The SBL has succeeded in diversifying its business from fund based to fee based activities and registered an average income of $14.649 \%$ while as ABBL has generated
$12.008 \%$ from this activity. The ABBL, in view of the squeezing of spread scenario needs to add more fee based products and services in its portfolio. However, the productivity ratios like earnings per employee and expenditure per employee are more in case of $\mathrm{ABBL}$ compare to the SBL. The SBL has generated an average Net Interest margin of 0.032 compare to 0.027 generated by ABBL. However, return on assets is more $(1.485 \%)$ in case of ABBL compare to SBL $(0.916 \%)$. The spread management shows that PNB has received more interest on advances viz.-a-viz. interest paid on deposits, the average spread ratio being 0.339 . With average spread ratio of 0.311 , the ABBL has not been as successful as SBL in the management of its spread (interest received-interest paid). The liquidity in a bank is what blood is in a human body. The bank should be in a position to meet its liability holders as an when demand arises. Thus the appropriate mixture of liquid and non-liquid asset is maintained. For this an appropriate strategy of liability and assets management is designed. The liquidity position of $\mathrm{ABBL}$, with 0.144 liquid assets to deposits ratio is better than the SBL where the same ratio is only 0.095. However, the investment to deposit ratio is better in SBL (0.448) compare to ABBL (0.441).

\section{REFERENCES}

[1] Ajit,D.and Bangar,R.D. "The role and performance of private sector banks in India-1991-92 to1996-97." Political Economy Journal of India. Jan.-June, 7(1 and 20), 7-20,1998.

[2] Bhatia, S. and Verma, S. "Factors Determining Profitability of public sector banks in India: An application of Multiple Regression Model.” Prajnan, XXVII(4), 433-445,1998-99.

[3] Chidambaram, R.M. and Alamelu. "Profitability in Banks, a Matter of Survival.” The Banker, May, 18, 1-3, 1994.

[4] Dasgupta, D. "A study of the performance of Public Sector Banks in India during the Post-Liberalisation Era." Business 
Studies, Department of Commerce, University of Calcutta, January \& July, XXIII(1 and 2), 103-114, 2000.

[5] Desai, B. H. and Farmer, M. J. "Taxonomic evaluation of banks' profitability performance." ICWAI-The Management Accountant, 36(12), 885-891, 2001.

[6] Duncan, E. and Elliot, G. "Efficiency, customer service and financial performance among Australian Financial institutions." The International Journal of bank marketing, 22(5), 319-342, 2004.

[7] Edisurya, P. and Fang, V. "Financial deregulation and financial performance: a comparative study of Indian banks and selected OECD banks." Journal of Accounting and finance, 15(2), 5-24, 2001.

[8] Kapil, S. K., Kanwal N. and Nagar, K. N. "Benchmarking Performance of Indian Public Sector Commercial Banks." Indian Journal of Accounting, XXXIV(1), 24-28, 2003.

[9] Kaur, G. and Bhatia, A. S. "Imapct of 'SLR' on Income and Profitability of Public Sector Banks in India." Political Economy Journal of India, 7(1 and 2), 60-67, 1998.

[10] Khatik, S.K. "Financial Appraisal of IDBI Bank Ltd." Indian Journal of Accounting, XXXIII, 35-42, 2002.

[11] Mittal, R.K. "Performance evaluation of RRBs: A case study of hisar-sirsa-kshetriya gramin bank." The Management Accountant, 36(11), 833-844, 2001.

[12] Mohanty, B.K. "Role of Loan Classification Norms and Legal measures in NPA Management of Banks." The Management Accountant, 41(1), 7-12, 2006.

[13] Padmanabhan, K. "Financial Sector reforms and the performance of Commercial Banks." Political Economy Journal of India, 7(1 and 2), 72-85, 1998.

[14] Panigrahi, N.M. "Treasury Management and Wholesale Banking." Premlata Devi, Paradip Port Orrisa, 147-151, 1996.

[15] Passah, P.M. "Banking and Financial Sector Reforms in India-Rationale, Progress, Efficacy and Future Agenda." Political Economy Journal of India, 7(1 and 2), 18-38, 2001.

[16] Purohit, K. K. and Mazumdar, B. C. "Post-Martem of Financial Performance and Prediction of Future Earning Capability of a Bank: An Application of CAMEL Rating and Balanced Scorecard." Indian Journal of Accounting, XXXIV(1), 8-16, 2003

[17] Reddy, G. S. (2004). "Management of Non-Performing Assets (NPA's) in Public Sector Banks." Journal of Banking and Finance, XVII(3), 17-21, 2004.

[18] Sangmi, M. "Profitability Management in Commercial Banks: An Exploratory Study." The Business Review- Journal of the Faculty of Commerce and Management Studies- The University of Kashmir, Srinagar, 8(1 and 2), 36-49, 2002.

[19] Sarkar, P.C. and Das. A. "Development of Composite Index of Banking Efficiency: The Indian Case." Reserve Bank of India Occasional Papers, 18, 1-10, 1997.

[20] Sikider, S. and Mukherjee, K. "Banking and Finance Basle norms: cost-income measurement impact on commercial banks." The Management Accountant, 36(7), 492-495, 2001.

[21] Sinkey, J. and F. JR. "Commercial Bank Financial Management." Prentice Hall International, Inc. 69-137, 238-260, 1998. 